\title{
ALGORITMA KEKANGAN MULTI TITIK DALAM ANALISIS STRUKTUR DENGAN METODE MATRIKS
}

\author{
Binsar Hariandja \\ Guru Besar Teknik Sipil, Institut Teknologi Bandung \\ Binsar_hariandja@ymail.com
}

\begin{abstract}
ABSTRAK
Makalah ini menyajikan metode penerapan hubungan antara beberapa derajat kebebasan sistem struktur atas persamaan keseimbangan sistem struktur. Metode ini, yang dinamakan algoritma kekangan multi titik, menerapkan persamaan kekangan langsung ke dalam persamaan keseimbangan struktur, tanpa merubah ukuran dari pada matriks kekakuan struktur. Metode dapat diterapkan kepada beberapa kasus, termasuk problem struktur dengan amblas, permodelan struktur tiga dimensi menjadi dua dimensi, dan problem struktur dengan perpindahan yang diketahui (prescribed displacement problem).
\end{abstract}

Kata kunci: Kekangan, multi titik.

\section{PENDAHULUAN}

Proses analisis struktur dengan metoda perpindahan mencakup penentuan vektor perpindahan akibat gaya luar yang disusun sebagai vektor gaya sebagai mana tertuang dalam persamaan keseimbangan struktur. Perpindahan global ini kemudian digunakan untuk menyusun vektor perpindahan elemen dalam tata sumbu global, merotasikannya ke tata sumbu lokal sebelum mengalikan hasilnya dengan matriks kekakuan elemen untuk mendapatkan gaya-gaya dalam elemen, yang ditambahkan dengan gaya-gaya ujung jepit untuk mendapatkan gaya-gaya final dalam elemen-elemen.

Dalam terapan sering dihadapi berbagai kasus di mana yang bekerja atas struktur bukan merupakan beban atau gaya, namun sebagai bentuk pengaruh yang tidak dapat dikuantifisir sebagai gaya namun pada akhirnya menimbulkan perpindahan dan gaya reaksi dalam struktur. Kejadian ini khususnya ditemukan dalam kasus sistem struktur yang statis tidak tentu. Contoh-contoh dari pada pengaruh luar semacam ini antara lain penurunan (settlement) dari pada perletakan, perobahan suhu dan kesalahan pemotongan dan pemasangan komponen.

Dalam analisis, akibat dari pada pengaruh luar semacam itu dapat diintrodusir sebagai perpindahan yang diketahui atau hubungan antara beberapa komponen perpindahan di beberapa titik simpul. Yang disebutkan terakhir ini dinamakan kekangan multi titik (multi-point constraint) yang menjadi bahan bahasan dasar dalam bab ini. Bahasan dimulai dari pada bentuk persamaan kekangan multi titik, formulasi serta algoritma, dan pada akhirnya memberikan contoh penerapan.

Algoritma Kekangan Multi Titik Dalam Analisis Struktur Dengan Metode Matriks 


\section{KEKANGAN MULTI TITIK}

Secara umum, analisis struktur dengan metoda perpindahan [1-7] pada akhirnya bermuara kepada penyelesaian sistem persamaan keseimbangan simultan

$$
[K]\{U\}=\{P\}
$$

yang perlu diselesaikan untuk mendapatkan vektor perpindahan $\{U\}$ yang koresponden dengan vektor gaya $\{P\}$ yang diketahui.

Selain memenuhi kriteria keseimbangan yang tersirat dalam persamaan simultan tersebut, vektor perpindahan $\{U\}$ juga misalnya harus memenuhi persyaratan tambahan berupa kaitan antara beberapa komponen perpindahan yang nota bene berada pada beberapa titik simpul, dengan hubungan sesamanya yang dinyatakan dalam bentuk matriks.

$$
[A]\left\{U_{C}\right\}=\{B\}
$$

dalam mana $\left\{U_{C}\right\}$ mencakup beberapa atau keseluruhan dari pada komponen perpindahan $\{U\}$. Sebagai contoh, untuk sistem struktur balok dengan perletakan miring (skew-support) seperti dalam Gambar 1, keseimbangan struktur dimanifestasikan oleh Pers. (1) dalam bentuk

$$
\left[\begin{array}{llll}
K_{11} & K_{12} & K_{13} & K_{14} \\
K_{21} & K_{22} & K_{23} & K_{24} \\
K_{31} & K_{32} & K_{33} & K_{34} \\
K_{41} & K_{42} & K_{43} & K_{44}
\end{array}\right]\left\{\begin{array}{l}
U_{1} \\
U_{2} \\
U_{3} \\
U_{4}
\end{array}\right\}=\left\{\begin{array}{l}
P_{1} \\
P_{2} \\
P_{3} \\
P_{4}
\end{array}\right\}
$$

dengan solusi bahwa perpindahan ujung balok di arah tegak lurus arah pergerakan rol, harus bernilai nol. Untuk dapat melakukan hal ini, maka perpindahan global struktur dalam Gambar 1(a) dirotasikan ke arah seperti dalam Gambar 1(b) dengan hubungan

$$
-U_{3} \sin \phi+U_{4} \cos \phi=0
$$

yang dapat dituliskan dalam formulasi matriks sebagai

$$
[-\sin \phi+\cos \phi]\left\{\begin{array}{l}
U_{3} \\
U_{4}
\end{array}\right\}=\{0\}
$$

Dengan demikian, untuk contoh ini, bentuk dalam Pers. (2) diperoleh dengan 


$$
\begin{aligned}
{[A] } & =\left[\begin{array}{ll}
-\sin \phi+\cos \phi &
\end{array}\right] \\
\left\{U_{C}\right\} & =\left\{\begin{array}{ll}
U_{3} & U_{4}
\end{array}\right\} \\
\{B\} & =\{0\}
\end{aligned}
$$

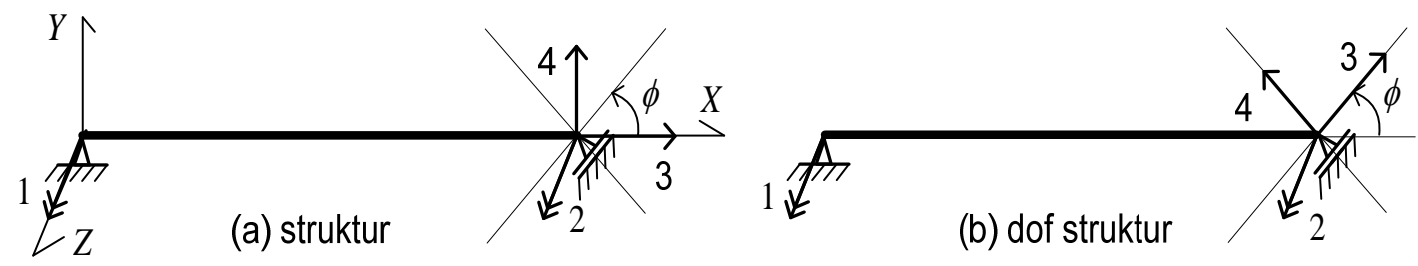

\section{Gambar 1. Struktur dengan perletakan miring.}

Persyaratan dalam Pers. (4) yang dituliskan dalam bentuk matriks dalam Pers. (5) merupakan kekangan (constraint) yang harus dipenuhi oleh solusi $\{U\}$ dari Pers. (1).

Contoh berikutnya adalah sistem struktur balok di atas tiga perletakan seperti dalam Gambar 2, dalam mana perletakan pada ujung $C$ mengalami amblas sebesar $\Delta$ ke bawah. Selain akibat gaya luar, amblasan ini akan menimbulkan gaya-gaya dalam balok. Untuk dapat memperhitungkan pengaruh dari amblasan, kebebasan perpindahan vertikan di titik $C$ diaktifkan sehingga ada empat komponen perpindahan struktur. Dengan derajat kebebasan struktur seperti dalam Gambar 2(b), persamaan keseimbangan diberikan identik dengan bentuk dalam Pers. (3) dengan kekangan

$$
U_{4}=-\Delta
$$

atau

$$
\left\{U_{4}\right\}=\{-\Delta\}
$$

Dengan demikian, untuk contoh ini, bentuk dalam Pers. (2) diperoleh dengan

$$
\begin{gathered}
{[A]=[1]} \\
\left\{U_{C}\right\}=\left\{U_{4}\right\} \\
\{B\}=\{-\Delta\}
\end{gathered}
$$

Untuk perletakan tanpa amblasan, diperoleh

$$
U_{4}=0
$$

atau

$$
\left\{U_{4}\right\}=\{0\}
$$


yang dinamakan kekangan absolut (restraint).
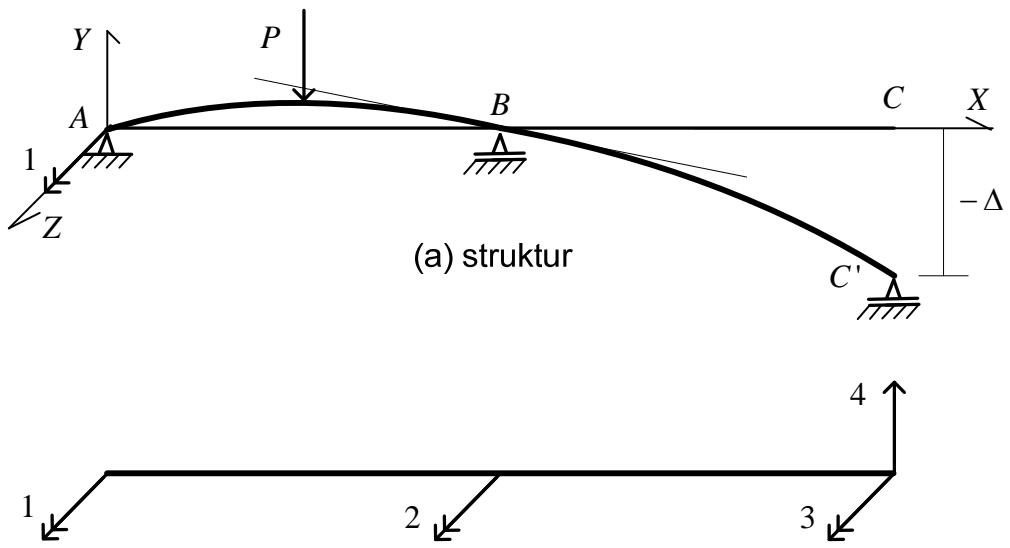

(b) dof struktur

Gambar 2. Struktur balok dengan amblasan perletakan.

Contoh lainnya adalah sistem struktur portal ruang seperti dalam Gambar 3, yang dalam analisis diambil penyederhanaan dengan menganggap lantai sebagai diafragma kaku, sedemikian hingga perpindahan horisontal kepala-kepala atas kolom berpindah seragam di arah horisontal. Asumsi ini didekati dengan suatu model diskrit dalam mana ketiga portal bidang dijejer sebidang seperti dalam Gambar 3(b).
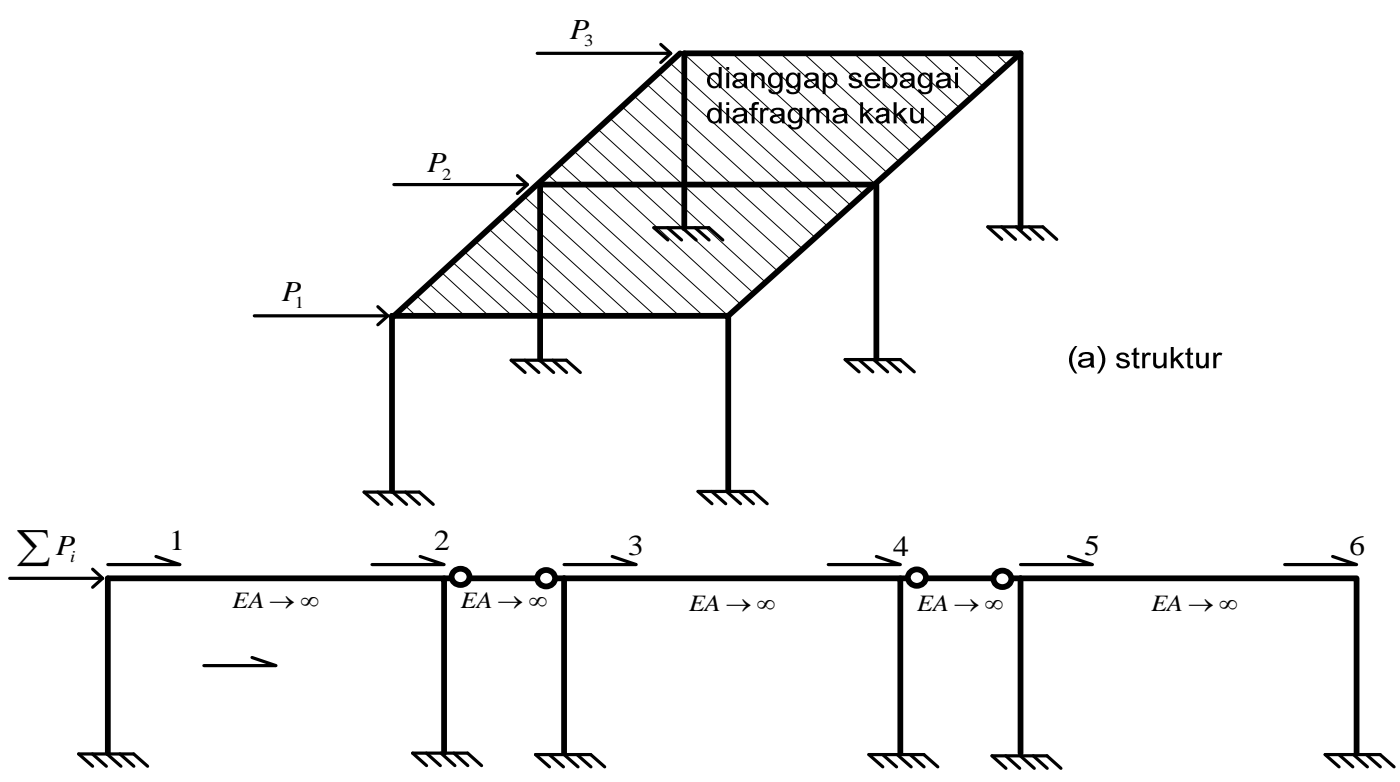

(b) model diskrit

Gambar 3. Struktur portal ruang dengan lantai sebagai diafragma. 
Perpindahan horisontal seragam ini dimimik dengan pemberian elemen-elemen pendel dengan kekakuan aksial $E A \rightarrow \infty$ sedemikian hingga hanya ada 7 derajat kebebasan, berupa 6 rotasi titik simpul kepala kolom dan 1 perpindahan horisontal lantai (dus juga kepala kolom).

Berikut ini kita akan menurunkan formulasi dalam mana sistem persamaan keseimbangan struktur dalam Pers. (1) digabungkan dengan kekangan dalam Pers. (2) dalam suatu sistem persamaan simultan, yang solusinya otomatis memenuhi baik persamaan keseimbangan maupun persyaratan kekangan.

\section{SISTEM PERSAMAAN MODIFIKASI DENGAN KEKANGAN}

Untuk memulai formulasi, kita pertama-tama memeriksa ukuran dari pada matriks koefisien $[A]$ dalam persamaan kekangan. Jika ukuran matriks ini adalah $(p \times q)$, maka vektor perpindahan terkekang $\left\{U_{C}\right\}$ dipartisi atas tiga bagian, yaitu atas sub-vektor $\left\{U_{m}\right\}$ yang berukuran $(q-p) \times 1$ serta yang mencakup komponen perpindahan yang dianggap atau dipandang sebagai komponen perpindahan pengekang (master, diberi indeks $m$ ), dan sub-vektor $\left\{U_{s}\right\}$ yang berukuran $(p \times 1)$ serta yang mencakup komponen perpindahan yang dianggap atau dipandang sebagai komponen perpindahan terkekang (slave, diberi indeks $s$ ).

Bagian ketiga mencakup sisa komponen perpindahan lainnya yang bebas serta tidak terlibat dalam persamaan kekangan, yang dinamakan sub-vektor $\left\{U_{f}\right\}$ yang diberi indeks $f$. Dengan demikian, vektor perpindahan struktur dipartisi dalam bentuk [3]

$$
\{U\}=\left\{\begin{array}{c}
\left\{U_{f}\right\} \\
\cdots \\
\left\{U_{m}\right\} \\
\cdots \\
\left\{U_{s}\right\}
\end{array}\right\}
$$

yang sekaligus secara koresponden membagi matriks kekakuan dan vektor perpindahan struktur atas partisi yang koresponden, dalam bentuk 


$$
\left[\begin{array}{ccccc}
\left\lfloor K_{f f}\right\rfloor & \vdots & \left\lfloor K_{f m}\right\rfloor & \vdots & \left\lfloor K_{f s}\right] \\
\cdots & \cdots & \cdots & \cdots & \cdots \\
{\left[K_{m f}\right]} & \vdots & {\left[K_{m m}\right]} & \vdots & {\left[K_{m s}\right]} \\
\cdots & \cdots & \cdots & \cdots & \cdots \\
{\left[K_{s f}\right]} & \vdots & {\left[K_{s m}\right]} & \vdots & {\left[K_{s s}\right.}
\end{array}\right]\left\{\begin{array}{c}
\left\{U_{f}\right\} \\
\cdots \\
\left\{U_{m}\right\} \\
\cdots \\
\left\{U_{s}\right\}
\end{array}\right\}=\left\{\begin{array}{c}
\left\{P_{f}\right\} \\
\cdots \\
\left\{P_{m}\right\} \\
\cdots \\
\left\{P_{s}\right\}
\end{array}\right\}
$$

dan persamaan kekangan dalam bentuk

$$
\left.\left[A_{m}\right]:\left[A_{s}\right]\right]\left\{\begin{array}{c}
\left\{U_{m}\right\} \\
\ldots \\
\left\{U_{s}\right\}
\end{array}\right\}=\{B\}
$$

Sebelum kekangan dalam Pers. (14) diterapkan atas Pers. (13), kita melihat bahwa kekangan dalam Pers. (14) identik dengan penerapan vektor kekangan atas bagian dalam partisi bawah Pers. (13), yaitu dengan dikerjakannya vektor gaya $\left\{R_{s}\right\}$ sedemikian hingga

$$
\left\lfloor K_{s f}\right\}\left\{U_{f}\right\}+\left[K_{s m}\right]\left\{U_{m}\right\}+\left[K_{s s}\right]\left\{U_{s}\right\}=\left\{P_{s}\right\}+\left\{R_{s}\right\}
$$

Berikutnya, vektor perpindahan $\{U\}$ dalam Pers. (13) diberi tanda yang menyatakan bahwa vektor ini belum termodifikasi oleh penerapan kekangan, yaitu dengan memberi tanda garis di atasnya. Jadi, Pers. (13) menjadi

$$
\left[\begin{array}{ccccc}
{\left[K_{f f}\right]} & \vdots & {\left[K_{f m}\right]} & \vdots & {\left[K_{f s}\right]} \\
\cdots & \cdots & \cdots & \cdots & \cdots \\
{\left[K_{m f}\right]} & \vdots & {\left[K_{m m}\right]} & \vdots & {\left[K_{m s}\right]} \\
\cdots & \cdots & \cdots & \cdots & \cdots \\
{\left[K_{s f}\right]} & \vdots & {\left[K_{s m}\right]} & \vdots & {\left[K_{s s}\right]}
\end{array}\right]\left\{\begin{array}{c}
\left\{\bar{U}_{f}\right\} \\
\cdots \\
\left.\bar{U}_{m}\right\} \\
\cdots \\
\left.\bar{U}_{s}\right\}
\end{array}\right\}=\left\{\begin{array}{c}
\left\{P_{f}\right\} \\
\cdots \\
\left\{P_{m}\right\} \\
\cdots \\
\left\{P_{s}\right\}
\end{array}\right\}
$$

Selanjutnya, vektor perpindahan $\{\bar{U}\}$ dalam Pers. (16) dikaitkan dengan vektor perpindahan $\{U\}$ dengan transformasi

$$
\left\{\begin{array}{c}
\left\{\bar{U}_{f}\right\} \\
\cdots \\
\left.\bar{U}_{m}\right\} \\
\cdots \\
\left.\bar{U}_{s}\right\}
\end{array}\right\}=\left[\begin{array}{ccccc}
{[I]} & \vdots & {[0]} & \vdots & {[0]} \\
\cdots & \cdots & \cdots & \cdots & \cdots \\
{[0]} & \vdots & {[I]} & \vdots & {[0]} \\
\cdots & \cdots & \cdots & \cdots & \cdots \\
{[0]} & \vdots & {\left[A_{m}\right]} & \vdots & {\left[A_{s}\right.}
\end{array}\right]\left\{\begin{array}{c}
\left\{U_{f}\right\} \\
\cdots \\
\left\{U_{m}\right\} \\
\cdots \\
\left\{U_{s}\right\}
\end{array}\right\}-\left\{\begin{array}{c}
\{0\} \\
\cdots \\
\{0\} \\
\cdots \\
\{0\}
\end{array}\right\} \equiv[R]\{U\}-\left\{B^{\prime}\right\}
$$

dalam mana sub-persamaan dalam partisi terbawah, memberikan 


$$
\left\{\bar{U}_{s}\right\}=\left[A_{m}\right]\left\{U_{m}\right\}+\left[A_{s}\right]\left\{U_{s}\right\}-\{B\}
$$

Merujuk kepada bentuk dalam Pers. (18), pemenuhan syarat kekangan dalam Pers. (14) identik dengan penerapan kekangan

$$
\left\{\bar{U}_{s}\right\}=\{0\}
$$

atas bentuk dalam Pers. (16). Hal ini dapat dilakukan dengan menerapkan modifikasi atas Pers. (16) menjadi

$$
\left[\begin{array}{ccccc}
{\left[K_{f f}\right]} & \vdots & {\left[K_{f m}\right]} & \vdots & {[O]} \\
\cdots & \cdots & \cdots & \cdots & \cdots \\
{\left[K_{m f}\right]} & \vdots & {\left[K_{m m}\right]} & \vdots & {[O]} \\
\cdots & \cdots & \cdots & \cdots & \cdots \\
{[O]} & \vdots & {[O]} & \vdots & {\left[K_{s s}\right]}
\end{array}\right]\left\{\left\{\begin{array}{c}
\left.\bar{U}_{f}\right\} \\
\cdots \\
\left.\bar{U}_{m}\right\} \\
\cdots \\
\left.\bar{U}_{s}\right\}
\end{array}\right\}=\left\{\begin{array}{c}
\left\{P_{f}\right\}-\left[K_{f s}\right]\{B\} \\
\cdots \\
\left\{P_{m}\right\}-\left[K_{m s}\right]\{B\} \\
\cdots \\
\{O\}
\end{array}\right\}\right.
$$

atau

$$
\left[K_{m}^{\prime}\right][\bar{U}\}=\left\{P^{\prime}\right\}
$$

Kita sekarang memisalkan suatu medan perpindahan maya dengan kinematika yang sama dengan yang ada dalam Pers. (17), yaitu

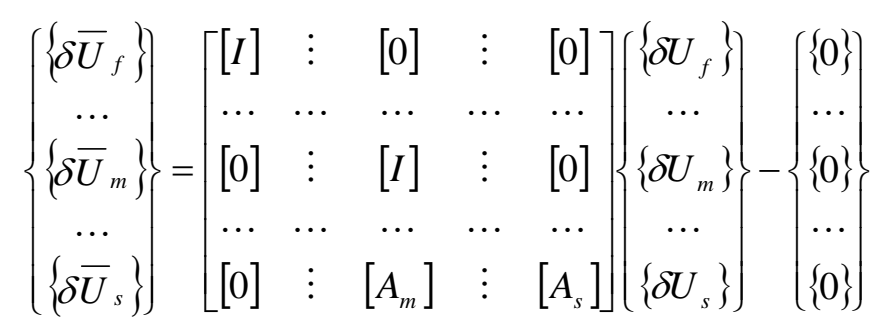

Pemasukan bentuk dalam Pers. (17) ke dalam Pers. (20) serta pengalian dari persamaan yang diperoleh dengan bentuk Pers. (22) dari depan, memberikan hasil sebagai berikut.

$$
\{\delta U\}^{T}[R]^{T}\left[K_{m}\right][R]\{U\}=\{\delta U\}^{T}[R]^{T}\left\{\left\{P^{\prime}\right\}+\left\{B^{\prime}\right\}\right\}
$$

Karena $\{\delta U\}$ merupakan perpindahan maya yang bersifat sembarang namun secara kinematis dimungkinkan (kinematically admissible), maka Pers. (23) memberikan 


$$
\begin{aligned}
& {\left[\begin{array}{ccccc}
{\left[K_{f f}\right]} & \vdots & {\left[K_{f m}\right]} & \vdots & {[O]} \\
\ldots & \ldots & \cdots & \cdots & \cdots \\
{\left[K_{m f}\right]} & \vdots & {\left[K_{m m}\right]+\left[A_{m}\right]^{T}\left[K_{s s}\right]\left[A_{m}\right]} & \vdots & {\left[A_{m}\right]^{T}\left[K_{s s}\right]\left[A_{s}\right]} \\
\cdots & \cdots & \cdots & \cdots & \cdots \\
{[O]} & \vdots & {\left[A_{s}\right]^{T}\left[K_{s s}\right]\left[A_{m}\right]} & \vdots & {\left[A_{s}\right]^{T}\left[K_{s s}\right]\left[A_{s}\right]}
\end{array}\right]\left\{\begin{array}{c}
\left\{U_{f}\right\} \\
\cdots \\
\left\{U_{m}\right\} \\
\cdots \\
\left\{U_{s}\right\}
\end{array}\right\}} \\
& =\left\{\begin{array}{c}
\left\{P_{f}\right\}-\left[K_{f s}\right]\{B\} \\
\cdots \\
\left\{P_{m}\right\}+\left[A_{m}\right]^{T}\left[K_{s s}\right]\{B\}-\left[K_{m s}\right]\{B\} \\
\cdots \\
{\left[A_{s}\right]^{T}\left[K_{s s}\right]\{B\}}
\end{array}\right\}
\end{aligned}
$$

Mengamati bentuknya, terlihat bahwa Pers. (24) merupakan perpaduan dari bentuk persamaan keseimbangan dalam Pers. (13), dan bentuk kekangan dalam Pers. (14). Dengan demikian, solusi dari persamaan ini secara otomatis memenuhi kriteria keseimbangan dan syarat kekangan. Menarik untuk melihat bahwa matriks kekakuan yang baru dalam Pers. (24) tetap bersifat simetri. Solusi yang diperoleh dari Pers. (24) kemudian dapat dimasukkan ke dalam Pers. (15) untuk menghitung gaya-gaya di arah kekangan, yaitu

$$
\left\{R_{s}\right\}=\left[K_{s f}\right\}\left\{U_{f}\right\}+\left[K_{s m}\right]\left\{U_{m}\right\}+\left[K_{s s}\right]\left\{U_{s}\right\}-\left\{P_{s}\right\}
$$

Sebelum menyajikan algoritma operasi penerapan kekangan yang telah dipaparkan di depan, maka terlebih dahulu diberikan beberapa komentar yang menyangkut persamaan termodifikasi dalam Pers. (24). Lazimnya, komponen perpindahan pengekang dan terkekang tidak selalu menempati lokasi yang berurutan dalam vektor perpindahan. Jika demikian halnya, maka penerapan kekangan atas persamaan simultan dapat dilakukan secara baris per baris dari persamaan kekangan.

Hal berikutnya yang penting untuk dicatat dan diperhatikan adalah bahwa penerapan syarat kekangan yang menghasilkan persamaan termodifikasi dalam Pers. (24), menghasilkan matriks kekakuan termodifikasi yang memiliki besar paroh lajur yang berbeda dibandingkan dengan besar paroh lajur matriks kekakuan awal. Hal ini perlu diperhatikan untuk menyiapkan lokasi penyimpanan matriks kekakuan termodifikasi yang memadai. 


\section{4 . ALGORITMA KEKANGAN}

Algoritma kekangan sekarang dapat disusun dengan urutan tindakan operasional sebagai berikut .

1. Rakitkan persamaan keseimbangan struktur global seperti dalam Pers. (1).

2. Susun syarat kekangan dalam bentuk matriks seperti dalam Pers. (2).

3. Berdasarkan Pers. (14), susun persamaan seperti dalam Pers. (15) yang perlu disimpan untuk nantinya dapat dimanfaatkan menghitung gaya reaksi di arah perpindahan terkekang $\left\{R_{s}\right\}$.

4. Modifikasi sistem persamaan keseimbangan seturut dengan Pers. (24).

5. Solusikan persamaan tersebut dalam butir 4 untuk mendapatkan vektor perpindahan struktur, yang memenuhi kriteria keseimbangan dan syarat kekangan sekaligus.

6. Gunakan vektor perpindahan dalam butir 5 untuk menghitung reaksi di arah kekangan dalam Pers. (25).

7. Hitung gaya-gaya reaksi elemen-elemen dengan prosedur yang standar.

\section{CONTOH PENERAPAN}

Untuk meningkatkan pengertian serta memperdalam pemahaman tentang isi bahasan dalam bab ini, maka berikut ini disajikan beberapa contoh terkait.

Pertama, struktur balok tunggal prismatis berbentang $L$ dalam Gambar 4, mengalami amblas pada perletakan $B$. Tentukan gaya reaksi balok dan perletakan akibat amblasan tersebut. Sistem dimodel dengan suatu elemen dengan kebebasan seperti dalam Gambar 4(b) dengan perpindahan yang dapat memodelkan amblasan $-\Delta$. Persamaan keseimbangan yang koresponden dengan model ini adalah

$$
\left[\begin{array}{cc}
+12 E I / L^{3} & -6 E I / L^{2} \\
-6 E I / L^{2} & +4 E I / L
\end{array}\right]\left\{\begin{array}{l}
U_{1} \\
U_{2}
\end{array}\right\}=\left\{\begin{array}{l}
0 \\
0
\end{array}\right\}
$$

Persamaan kekangan adalah

$$
[1]\left\{U_{1}\right\}=\{-\Delta\}
$$

Kemudian, baris pertama yang berkaitan dengan perpindahan ini dimodifikasi seturut dengan Pers. (25), yaitu

$$
R_{1}=\frac{12 E I}{L^{3}} U_{1}-\frac{6 E I}{L^{2}} U_{2}
$$


Perhatikan bahwa sub-vektor perpindahan $\left\{U_{m}\right\}$ tidak muncul dalam Pers. (27). Modifikasi persamaan simultan menurut Pers. (24) memberikan

$$
\left[\begin{array}{cc}
+12 E I / L^{3} & 0 \\
0 & +4 E I / L
\end{array}\right]\left\{\begin{array}{l}
U_{1} \\
U_{2}
\end{array}\right\}=\left\{\begin{array}{l}
+12 E I \Delta / L^{3} \\
-6 E I \Delta / L^{2}
\end{array}\right\}
$$

yang jika diselesaikan, menghasilkan

$$
\left\{\begin{array}{l}
U_{1} \\
U_{2}
\end{array}\right\}=\left\{\begin{array}{c}
-\Delta \\
-\frac{3 \Delta}{2 L}
\end{array}\right\}
$$
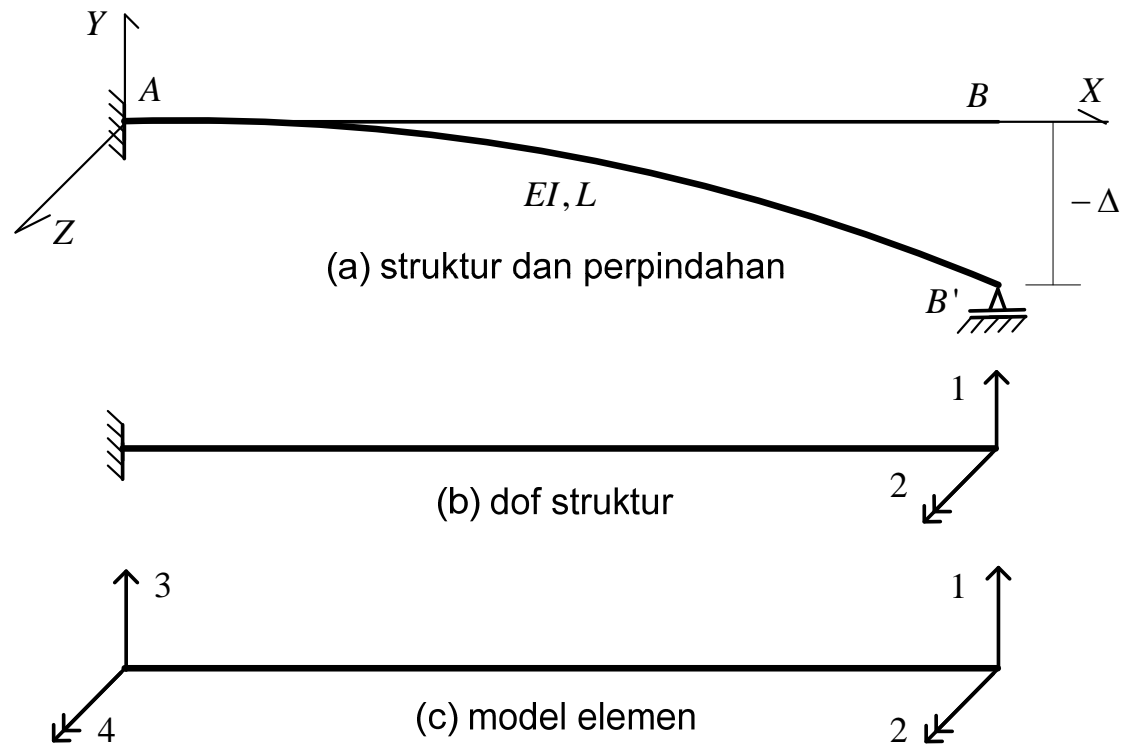

Gambar 4. Struktur contoh pertama.

Gaya reaksi batang menjadi

$$
\left\{\begin{array}{l}
p_{1} \\
p_{2} \\
p_{3} \\
p_{4}
\end{array}\right\}=\left[\begin{array}{cccc}
+12 E I / L^{3} & +6 E I / L^{2} & -12 E I / L^{3} & +6 E I / L^{2} \\
+6 E I / L^{2} & +4 E I / L & -6 E I / L^{2} & +2 E I / L \\
-12 E I / L^{3} & -6 E I / L^{2} & +12 E I / L^{3} & -6 E I / L^{2} \\
+6 E I / L^{2} & +2 E I / L & -6 E I / L^{2} & +4 E I / L
\end{array}\right]\left\{\begin{array}{c}
0 \\
0 \\
-\Delta \\
-3 \Delta /(2 L)
\end{array}\right\}=\left\{\begin{array}{c}
+3 E I \Delta / L^{3} \\
+3 E I \Delta / L^{2} \\
-3 E I \Delta / L^{3} \\
0
\end{array}\right\}
$$

Reaksi di arah $U_{1}$ dapat dihitung dengan Pers. (28), yaitu 


$$
R_{1}=\frac{12 E I}{L^{3}}(-\Delta)-\frac{6 E I}{L^{2}}\left(-\frac{3 \Delta}{2 L}\right)=-\frac{3 E I \Delta}{L^{3}}
$$

Contoh berikutnya, struktur balok prismatis menerus di atas 4 perletakan dengan sub-bentang masing-masing $L$ dibebani gaya terpusat $P$ di tengah sub-bentang kedua seperti dalam Gambar 5. Dengan menggunakan teknik kekangan, hitunglah momen reaksi pada ujung $A$ dan $D$ akibat gaya tersebut.

Untuk dapat menghitung momen reaksi yang dimintakan, maka digunakan jenis elemen seperti dalam Gambar 5(c). Untuk mendapatkan momen reaksi tersebut, rotasi di kedua titik yang diminati, dilepaskan sehingga kebebasan struktur seperti terlihat dalam Gambar 5(b). Persamaan keseimbangan menjadi

$$
\left[\begin{array}{cccc}
+\frac{4 E I}{L} & +\frac{2 E I}{L} & 0 & 0 \\
+\frac{2 E I}{L} & +\frac{8 E I}{L} & \frac{2 E I}{L} & 0 \\
0 & \frac{2 E I}{L} & \frac{8 E I}{L} & +\frac{2 E I}{L} \\
0 & 0 & \frac{2 E I}{L} & +\frac{4 E I}{L}
\end{array}\right]\left\{\begin{array}{l}
U_{1} \\
U_{2} \\
U_{3} \\
U_{4}
\end{array}\right\}=\left\{\begin{array}{c}
0 \\
-P L / 8 \\
+P L / 8 \\
0
\end{array}\right\}
$$

dan syarat kekangan adalah

$$
\left[\begin{array}{ll}
1 & 0 \\
0 & 1
\end{array}\right]\left\{\begin{array}{l}
U_{1} \\
U_{2}
\end{array}\right\}=\left\{\begin{array}{l}
0 \\
0
\end{array}\right\}
$$

Selanjutnya kekangan dalam Pers. (34) merobah baris ke-1 dan ke-4 Pers. (32) menurut Pers. (15) menjadi

$$
\begin{aligned}
& R_{1}=\frac{4 E I}{L} U_{1}+\frac{2 E I}{L} U_{2} \\
& R_{4}=\frac{2 E I}{L} U_{3}+\frac{4 E I}{L} U_{4}
\end{aligned}
$$

Sekarang, baris per baris kekangan dalam Pers. (34) diterapkan ke dalam Pers. (33) secara berturutan, dalam artian bahwa penerapan baris ke-2 dilakukan terhadap hasil modifkasi yang diperoleh setelah penerapan baris ke-1. Penerapan baris pertama memberikan,

$$
\left[\begin{array}{cccc}
+4 E I / L & 0 & 0 & 0 \\
0 & +8 E I / L & 2 E I / L & 0 \\
0 & 2 E I / L & 8 E I / L & +2 E I / L \\
0 & 0 & 2 E I / L & +4 E I / L
\end{array}\right]\left\{\begin{array}{l}
U_{1} \\
U_{2} \\
U_{3} \\
U_{4}
\end{array}\right\}=\left\{\begin{array}{c}
0 \\
-P L / 8 \\
+P L / 8 \\
0
\end{array}\right\}
$$




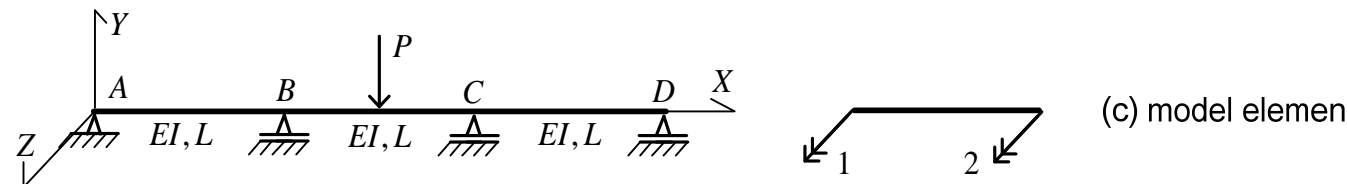

(a) struktur
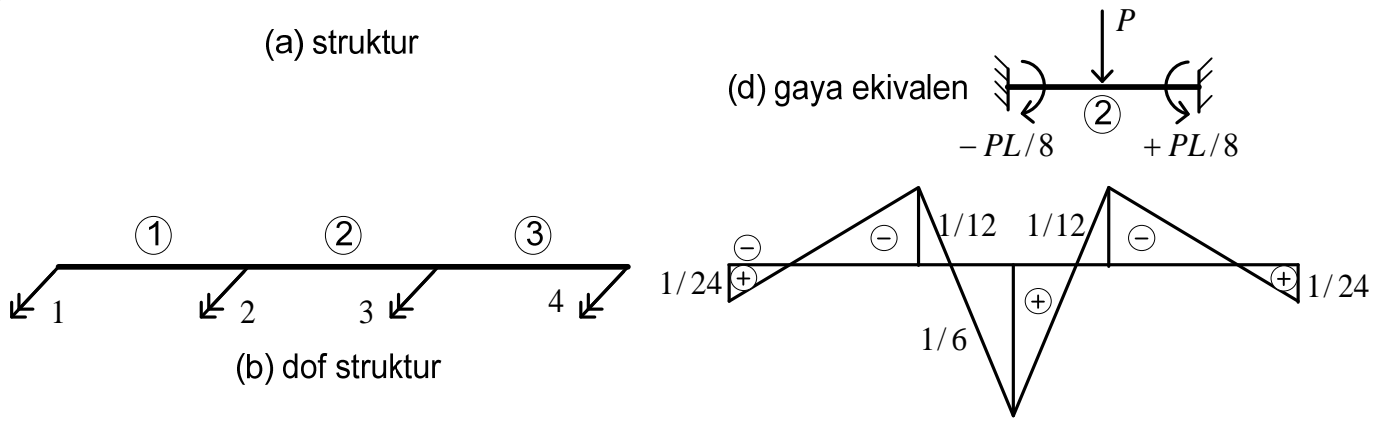

(e) bidang momen, $M / P L$

\section{Gambar 5. Struktur contoh kedua.}

Penerapan kekangan baris ke-2 atas Pers. (36) memberikan

$$
\left[\begin{array}{cccc}
+4 E I / L & 0 & 0 & 0 \\
0 & +8 E I / L & 2 E I / L & 0 \\
0 & 2 E I / L & 8 E I / L & 0 \\
0 & 0 & 0 & +4 E I / L
\end{array}\right]\left\{\begin{array}{c}
U_{1} \\
U_{2} \\
U_{3} \\
U_{4}
\end{array}\right\}=\left\{\begin{array}{c}
0 \\
-P L / 8 \\
+P L / 8 \\
0
\end{array}\right\}
$$

Solusi dari pada sistem persamaan termodifikasi ini adalah

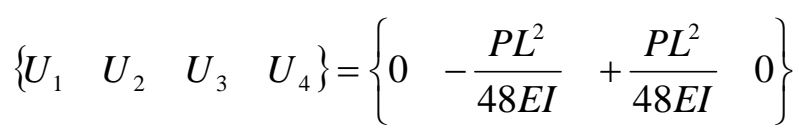

yang secara otomatis dan sekaligus memenuhi persamaan keseimbangan dan syarat kekangan. Reaksi momen di perletakan $A$ dan $D$ dihitung dengan Pers. (35) dengan hasil

$$
\begin{aligned}
& R_{1}=\frac{4 E I}{L}(0)+\frac{2 E I}{L}\left(-\frac{P L^{2}}{48 E I}\right)=-\frac{P L}{24} \\
& R_{4}=\frac{2 E I}{L}\left(-\frac{P L^{2}}{48 E I}\right)+\frac{4 E I}{L}(0)=+\frac{P L}{24}
\end{aligned}
$$

Gaya-gaya ujung elemen demi elemen dapat dihitung dengan cara yang standard, mulai dari penyusunan vektor perpindahan elemen dalam tata sumbu global, merotasikannya ke tata sumbu lokal, serta mengalikan hasilnya dari depan dengan matriks kekakuan, dan setelahnya menambahkannya dengan vektor gaya ujung jepit akibat beban luar. 


\section{KESIMPULAN}

Dari formulasi dan penerapan algoritma teknik operasi kekangan yang telah dibahas dalam bab ini, ditarik beberapa kesimpulan sebagai berikut. Pertama, penerapan algoritma kekangan dengan cara yang diusulkan, bersifat terintegral, standard serta tidak merobah ukuran matriks kekakuan. Yang berubah akibat penerapan kekangan adalah ukuran paroh lajur matriks kekakuan global struktur. Kemudian, perilaku matriks koefisien termodifikasi tetap baik serta tidak akan "ill-condition" seperti yang sering dihadapi beberapa teknik kekangan lainnya. Matriks kekakuan global struktur yang termodifikasi akibat penerapan kekangan, tetap bersifat simetris.

Dalam penerapan, dikemukakan beberapa saran sebagai berikut. Pertama, pada dasarnya teknik yang diusulkan juga dapat digunakan untuk beberapa kasus lain, misalnya penentuan solusi sistem persamaan simultan dengan syarat batas yang sering kita hadapi dalam problem fluida, rambat panas dan lain-lain. Cara di atas dapat diterapkan dalam suatu subroutine komputer secara mudah dan efisien. Khususnya, dalam problem rekayasa dengan syarat batas yang berobah secara quasi-statis dapat diterapkan dengan sangat baik.

\section{UCAPAN TERIMA KASIH}

Penulis mengucapkan terima kasih yang tulus kepada Prof. Robert B. Haber yang telah membimbing penulis dalam menyelesaikan program philosophy of doctor di Civil Engineering Department, University of Illinois at Urbana-Champaign. Ucapan terima kasih yang sama juga penulis haturkan kepada Prof. Jamshid Ghabouzzi yang telah mengajar penulis dalam analisis dengan metode matriks. Penulis menghaturkan terima kasih kepada David Ramot, ST yang telah mengetik naskah makalah ini dengan seksama.

\section{REFERENSI}

1. Argyris, J.M., dan Kelsey, S., Energy Theorems and Structural Analysis, Butterworth, London (1960).

2. Ghali, A., dan Neville, A.M., Structural Analysis: A Unified Classical and Matrix Approach, Chapman and Hall, London, edisi kedua (1978).

3. Hariandja, B.H., Analisis Struktur Berbentuk Rangka Dalam Formulasi Matriks, Penerbit Aksara Hutasada, Bandung, edisi pertama (1997).

4. Martin, H.C., Introduction to Matrix Methods of Structural Analysis, McGraw-Hill Company, New York (1966). 
5. Vanderbielt, M.D., Matrix Structural Analysis, Quantum Publishers, Inc., New York (1975).

6. Weaver Jr, W., dan Gere, J. M, Matrix Analysis of Framed Structures, Van Nostrand Company, New York, edisi kedua (1980).

7. Willems, N., dan Lucas Jr, W.M., Matrix Analysis for Structural Engineers, Prentice-Hall, Inc., Englewood Cliff, New Jersey (1968). 